Research Paper Vol 2, No 2, Tahun 2020

\title{
Jurnal - Pengaruh pencampuran bahan baku acacia crassicarpa, acacia mangium dan eucalyptus terhadap kualitas pulp
}

\author{
Rachmawati Apriani ${ }^{1}$, Putra Novianto ${ }^{1}$ \\ Program Studi Teknologi Pengolahan Pulp dan Paper, Institut Teknologi Sains Bandung \\ Jl. Ganesha Boulevard, Lot-A1 CBD Kota Deltamas, Cikarang Pusat, Bekasi \\ Email: rachmawatiapriani46@gmail.com
}

\begin{abstract}
Abstrak
Penelitian dengan judul "Pengaruh Pencampuran Bahan Baku Acacia Crassicarpa (AC), Acacia Mangium (AM) dan Eucalyptus(ECA) Terhadap Kualitas Pulp" bertujuan untuk mengetahui kualitas pulp yang dihasilkan dengan mencampurkan beberapa bahan baku dengan menggunakan metode kraft pulping. Parameter yang digunakan yaitu kappa number, viskositas, total solid, yield, brightness, Residual Effective Alkali (REA) dan reject. Rasio pencampuran bahan baku yang digunakan yaitu dengan pencampuran 2 bahan baku dan 3 bahan baku. Untuk pencampuran 2 bahan baku dilakukan dengan rasio ( $50: 50 ; 60: 40 ; 70: 30 ; 80: 20) \%$. Sedangkan untuk pencampuran 3 bahan baku menggunakan variasi (70:20:10)\%. Dengan adanya rasio pencampuran bahan baku dalam pembuatan pulp dapat mengetahui rasio campuran optimal yang dapat dilakukan antara ketiga bahan baku tersebut maupun kedua bahan baku yang digunakan. Dari semua variasi yang dilakukan didapatkan hasil optimal yaitu pada rasio AC 70\%:AM 20\%: ECA 10\% yang telah memenuhi standar parameter yang ditentukan, dengan nilai kappa number 20,65 , viskositas $1139,19 \mathrm{~cm}^{3} / \mathrm{g}$, yield $53,34 \%$, total solid $16,59 \%$, REA 9,95 g/l as $\mathrm{Na}_{2} \mathrm{O}$, reject $0,297 \%$, dan brightness $33,53 \%$ ISO.
\end{abstract}

Kata Kunci : pulp, parameter, acacia mangium, acacia crasicarpa, eucalyptus 


\section{JVTI}

JURNAL VOKASI

TEKNOLOGI INDUSTRI

\section{Research Paper Vol 2, No 2, Tahun 2020}

\section{Pendahuluan}

Perkembangan industri pulp dan kertas di Indonesia terus meningkat dari tahun ke tahun, namun belum dapat memenuhi semua kebutuhan dalam negeri dan permintaan ekspor yang terus mengalami peningkatan. Industri pulp dan kertas dalam negeri diperkirakan akan terus tumbuh pada tahun ini. Asosiasi Pulp dan Kertas Indonesia (APKI) memproyeksikan industri ini tumbuh 5\% pada 2019. Apalagi, peluang pasar masih terbuka dan kapasitas produksi pulp dan kertas meningkat karena ada perluasan. (Annisa Sulistyo Rini, 2019)

Untuk itu perlu adanya peningkatan yang diperlukan seperti teknologi dan bahan baku yang cukup dan memadai untuk kebutuhan ekspor dan impor. Kebutuhan bahan baku yang digunakan di Indonesia umumnya menggunakan jenis kayu hardwood yang telah dipersiapkan di area Hutan Tanaman Industri.

Tanaman kayu yang sering digunakan untuk pembuatan pulp berasal dari hutan tanaman industri (HTI) yang merupakan tanaman khusus sebagai bahan baku pulp dan kertas. Tanaman yang dikembangkan HTI di Indonesia berjenis daun lebar (hardwood). Beberapa kayu yang di budidayakan diantaranya Acacia crassicarpa, Acasia Mangium dan Eucalyptus. Ketiga kayu inilah yang menjadi prioritas sebagai bahan baku utama pulp dan kertas yang ada di Indonesia. Tanaman ini tumbuh baik pada tanah yang subur, tanah yang mengalami erosi dan tanah bekas perladangan, dan juga tanaman ini sangat baik untuk memberantas alang-alang karena cepat menutupi tanah. Penentuan jenis kayu yang akan dibudidayakan merupakan langkah awal yang penting karena akan berpengaruh besar terhadap segi teknis dan ekonomis dalam pengelolaan unit HTI untuk jangka waktu panjang.

Pada tempat yang baik, Acacia mangium dapat mencapai tinggi $30 \mathrm{~m}$ dengan diameter sampai 90 $\mathrm{cm}$ serta batang bebas cabang $10-15 \mathrm{~m}$. Rotasi tebang pohon ini mencapai 10 - 20 tahun dengan riap $45 \mathrm{~m}^{3} / \mathrm{h}$ /tahun. Sedangkan pada lahan yang terganggu, bekas perladangan, bekas terbakar, lereng yang terjal, tanaman ini tumbuh baik dan mampu memproduksi kayu $20 \mathrm{~m} 3 /$ ha/tahun. (Sindusuwarno dan Utomo, 1981). Sedangkan untuk Acacia crassicarpa produksi rata-rata pertahunnya mencapai $27 \mathrm{~m}^{3} /$ ha/tahun. Untuk spesies Eucalyptus yang ada di Indonesia diantaranya adalah Eucalyptus deglupta dengan riap 25-40 $\mathrm{m}^{3} / \mathrm{ha} /$ tahun, Acacia crassicarpa dengan riap 20-30 $\mathrm{m}^{3} / \mathrm{ha} /$ tahun dan Eucalyptus grandis dengan riap $25 \mathrm{~m}^{3} /$ ha/tahun. Pulp Acacia mangium memiliki kualitas yang cukup baik.
Potensi yang dimiliki oleh Acacia mangium memang cukup besar, tetapi terdapat masalah pada proses pembuatan pulpnya karena tingginya kandungan ekstraktif. Kandungan ekstraktif yang tinggi akan membuat kualitas pulp putih menjadi rendah, karena timbulnya noda (dirt), sehingga dapat mempengaruhi derajat cerah pulp.(Susi Sugesty dkk, 2015).

Pada salah satu penelitian pencampuran bahan baku Pinus pinaster dan Pupolus tremula oleh Gulsoy dan Tufek tahun 2013, di dapatkan hasil yaitu dengan nilai kappa number, viskositas, dan reject yang tinggi apabila rasio chip dari pinus lebih besar. Sehingga menyebabkan nilai screen yield menjadi rendah. Jika rasio dari populus lebih besar menjadikan pulp akan lebih mudah di lakukan penguraian atau beating. Sementara itu, rasio pinus yang lebih besar juga meningkatkan strength properties namun menurunkan brightness dan smothness. Faktor yang mempengaruhi kualitas pulp yaitu jenis serat. Oleh karena itu, sifat-sifat pulp yang diproduksi tergantung daripada jenis tumbuhan itu sendiri.

Di PT OKI Pulp and Paper kayu yang digunakan sebagai bahan baku pulp yaitu Acasia Crassicarpa, Acasia Mangium dan Eucalyptus. Dari ketiga bahan baku ini terkadang supply dari HTI tidak tentu, terkadang stok kayu Acacia crassicarpa banyak, Acacia mangium cukup sedikit dan juga Eucalyptus, dari ketiga bahan baku ini tentunya harus digunakan sebagai bahan baku untuk pemasakan, sehingga perlu adanya pencampuran dari ketiga bahan tersebut supaya persediaan chip ketiga bahan baku dapat digunakan dengan maksimal. Dari ketiga jenis kayu tersebut tentu memiliki perbedaan dan karakteristik masing-masing sehingga perlu adanya penelitian dengan judul "Pengaruh Pencampuran Bahan Baku Acacia Crassicarpa, Acacia Mangium Dan Eucalyptus Terhadap Kualitas Pulp" yang dapat menjadikan ketiga bahan baku tersebut dapat dilakukan pencampuran atau mixing yang optimal dalam proses pemasakan pulp.

\section{Tinjauan pustaka}

\subsection{Selulosa}

Selulosa merupakan konstituen utama kayu kira-kira 50-70\% bahan kering dalam kebanyakan spesies kayu adalah selulosa, terutama terdapat dalam dinding sel sekunder. Selulosa merupakan homopolisakarida yang tersusun atas unit-unit $\beta$ D Glukopiranosa yang terikat satu sama lain dengan ikatan-ikatan glikosida.

Molekul-molekul selulosa seluruhnya berbentuk linier dan mempunyai kecenderungan 


\section{JVTI}

JURNAL VOKASI

\section{Research Paper Vol 2, No 2, Tahun 2020}

kuat membentuk ikatan-ikatan 3unani3n intra dan intermolekul. Jadi, berkas-berkas molekul selulosa membentuk agregat 3unani3-sama dalam bentuk 3unani3n3il, pada tempat-tempat yang sangat teratur (kristalin) diselingi dengan tempattempat yang kurang teratur (amorf). Mikrofibril membentuk fibril-fibril dan akhirnya serat-serat selulosa. Sebagai akibat dari struktur yang berserat dan ikatan-ikatan 3unani3n yang kuat, selulosa mempunyai kekuatan 3unan yang tinggi dan tidak larut dalam kebanyakan pelarut.

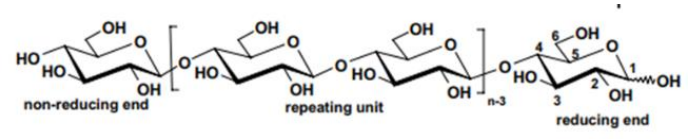

Gambar 1. Struktur selulosa

Sumber: Herbet Sixta (2006)

\subsection{Hemiselulosa}

Hemiselulosa termasuk dalam kelompok polisakarida heterogen yang dibentuk melalui jalan biosintesis yang berbeda dari selulosa. Hemiselulosa merupakan heteropolisakarida, hemiselulosa berfungsi sebagai bahan pendukung dalam dinding-dinding sel. Berbeda dengan selulosa yang mana polimernya dibentuk hanya dengan glukosa, hemiselulosa dibentuk dari berbagai gula seperti glukosa, mannosa, galaktosa, xylose dan arabinosa. Tergantung pada spesies tanaman, gula ini bersama asam uronat membentuk berbagai struktur polimer, beberapa ada yang berasosiasi dengan bagian selulosa, sementara yang lain lebih erat berasosiasi dengan lignin.

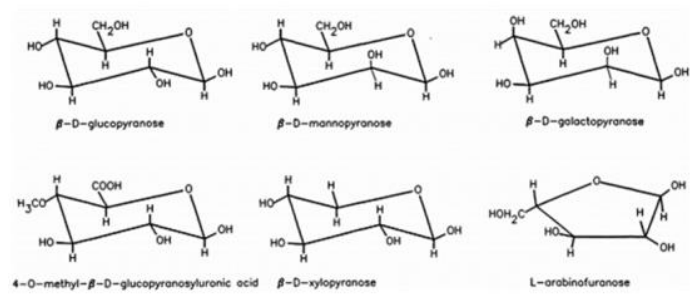

Gambar 2. Struktur hemiselulosa

Sumber: Pratima Bajpai (2018)

Ada berbagai jenis hemiselulosa spesies kayu yang berbeda memiliki hemiselulosa dengan komposisi yang berbeda. Hard wood lebih banyak memiliki xylan, soft wood lebih banyak memiliki glukosa. Tipe selulosa juga bervariasi tergantung letak hemiselulosa dan struktur kayu. Rantai hemiselulosa lebih pendek dari rantai selulosa. Hemiselulosa memiliki derajat polimerisasi lebih kecil yaitu 300. Hemiselulosa adalah polimer bercabang, atau tidak linear. Selama pembuatan pulp, hemiselulosa bereaksi lebih cepat dibandingkan selulosa.

\subsection{Lignin}

Dalam kebanyakan penggunaan kayu, lignin digunakan sebagai bagian penting kayu. Hanya dalam pembuatan pulp dan pengelantangan lignin dilepaskan dari kayu dalam bentuk terdegradasi dalam black liquor. Istilah holoselulosa digunakan untuk menggambarkan kandungan karbohidrat total serat. Selain bahan-bahan tanaman kayu, holoselulosa mengandung substansi amorf yang sangat terpolimerisasi yang disebut lignin. Peran utamanya adalah untuk membentuk lamella tengah, bahan antar sel yang menyatukan serat. Sebagian lignin juga terkandung dalam potongan melintang serat yang tersisa. Kimia lignin sangat kompleks. Struktur terutama terdiri dari unit-unit fenil propana yang dihubungkan bersama dalam tiga dimensi. Tiga hubungan antara rantai samping propana dan cincin benzena terputus selama pembuatan pulp kimia untuk memisahkan serat selulosa.

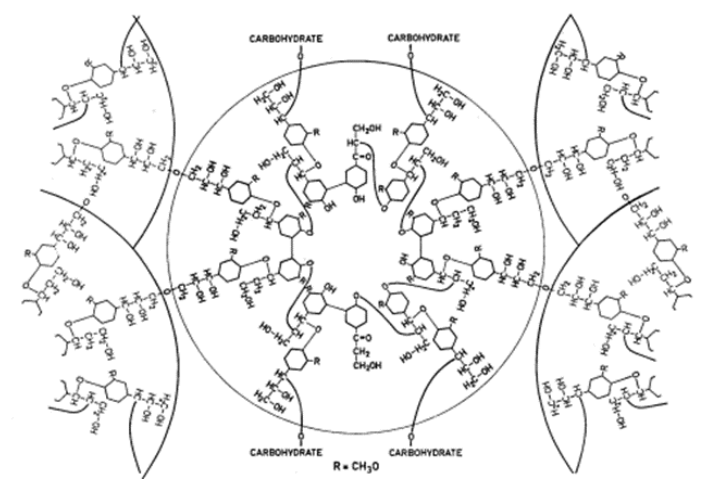

Gambar 3. Gambaran lignin yang mengikat selulosa Sumber: Gary A Smook (2002)

\subsection{Zat Ekstraktif}

Selain holoselulosa dan lignin, sejumlah zat yang beragam terdapat dalam serat asli, tergantung pada sumber tanaman, misalnya resin, asam lemak, terpentin dan alkohol. Sebagian besar zat ini larut dalam air atau pelarut organik netral, dan secara kolektif disebut ekstraktif. Komposisi kimia kayu diilustrasikan dalam gambar di bawah ini. Tujuan pemasakan secara kraft adalah pemisahan serat dari serpih kayu secara kimia dan melarutkan lignin semaksimal mungkin yang terdapat pada dinding serat. Jika hanya sedikit ekstraktif yang dapat diekstraksi, maka hal ini akan dapat menyebabkan masalah pitch dalam pembuatan pulp dan kertas. Pitch ini dapat menyebabkan endapan yang dapat lengket pada peralatan, seperti pada penyaring dan lembaran pembuatan kertas. 


\section{JVTI}

JURNAL VOKASI

\section{Research Paper Vol 2, No 2, Tahun 2020}

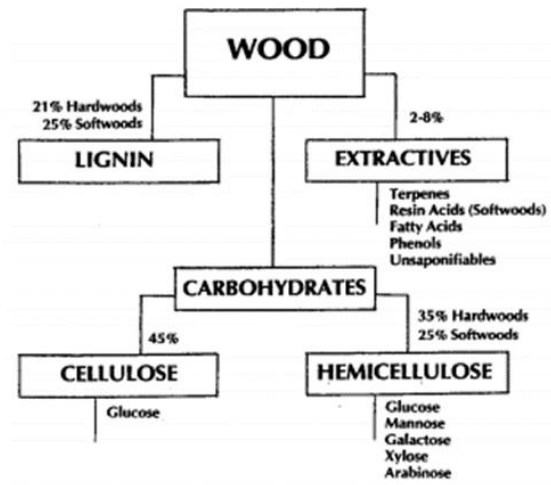

Gambar 4. Komponen kimia

Sumber: Gary A Smook (2002)

\subsection{Acacia $S p$}

Jenis tanaman acacia yaitu A. mangium Willd dan A. crassicarpa A. Cunn. Jenis ini dikembangkan sebagai tanaman pokok pada HTI, karena memenuhi persyaratan sebagai bahan baku kayu untuk 4unani4n pulp dan kertas, karena telah dikuasainya Teknik budidayanya. Pulau Sumatera 4unani4n wilayahnya terdiri atas lahan gambut, sehingga konsesi pengembangan HTI meliputi area lahan gambut. A. Crassicarpa dapat beradaptasi pada lahan gambut, sehingga terpilih sebagai tanaman HTI untuk lahan gambut, sedangkan A. Mangium hanya dapat dikembangkan pada lahan mineral. (Suhartati, dkk. 2014)

Tabel 1. Komponen kimia kayu kayu acacia crassicarpa dan acacia mangium

\begin{tabular}{|l|c|c|}
\hline \multicolumn{1}{|c|}{ Sifat Kimia Kayu } & $\begin{array}{c}\text { Acacia } \\
\text { crassicarpa }\end{array}$ & $\begin{array}{c}\text { Acacia } \\
\text { mangium }\end{array}$ \\
\hline Lignin (\%) & 26,00 & 27,07 \\
Selulosa Alfa (\%) & 48,52 & 51,81 \\
Kelarutan Air Dingin & 0,85 & 3,31 \\
$(\%)$ & 2,61 & 5,19 \\
Kelarutan Air Panas & 15,68 & 14,46 \\
$(\%)$ & 0,55 & 0,84 \\
Kelarutan NaOH 1\% & 1,96 & - \\
$(\%)$ & & \\
Kadar Abu (\%) & & \\
Ekstraktif (\%) & & \\
& & \\
\hline
\end{tabular}

Sumber: Haroen,dkk (1997)

Tabel 2. Morfologi serat kayu acacia crassicarpa dan acacia mangium

\begin{tabular}{|c|c|c|}
\hline $\begin{array}{c}\text { Sifat Fisik dan } \\
\text { Morfologi }\end{array}$ & $\begin{array}{c}\text { Acacia } \\
\text { crassicarpa }\end{array}$ & $\begin{array}{c}\text { Acacia } \\
\text { mangium }\end{array}$ \\
\hline Panjang Serat $(\mathrm{mm})$ & 1,34 & 1,40 \\
\hline
\end{tabular}

\begin{tabular}{|l|c|c|}
\hline Diameter Serat $(\mu)$ & 35,68 & 18,36 \\
Rungkle Ratio & 0,14 & 0,38 \\
Felting Ratio & 38,01 & 50,51 \\
Fleksibility Ratio & 0,88 & 0,72 \\
Coef. Rigidity & 0,06 & 0,14 \\
\hline \multicolumn{2}{|c|}{ Sumber: Suhartati, dkk (2014) }
\end{tabular}

Massa jenis pada tanaman atau kayu dapat dipengaruhi oleh beberapa hal seperti umur tanaman, sifat genetis selnya (a) tebal dinding serat, (b) ukuran serat dan (c) jumlah serta tipe sel dari (a) dan (b). Tebal dinding dan sel pembuluh (vessels), merupakan factor paling dominan yang dapat mempengaruhi massa jenis kayu, terutama pada kelompok Angisospermae jenis kayu daun lebar (hardwood). Massa jenis hardwood sangat berpengaruh terhadap kualitas serpih yang dihasilkan dan kebutuhan energi pada saat penyerpihan. Semakin tinggi massa jenisnya maka kualitas keseragaman serpih akan berkurang dan energi yang digunakan lebih tinggi. (Kellomaki, 1998)

Perbedaan massa jenis pada kayu atau serpih menyebabkan bahan kimia pemasak yang diperlukan lebih tinggi, kemudian memperlambat penetrasi zat kimia ke dalam serpih dan menambah waktu pemasakan. Sehingga ada beberapa cara dan strategi para industriawan dan praktisi untuk menanggulagi masalah masa jenis tersebut, yaitu dilakukan proses perlakuan awal (pre-treatment) secara mekanis terhadap serpih sebelum dilakukan pemasakan. (Wawan K, 2006). Kerapatan kayu (densitas) pada kayu Acacia berkisar $0,55 \mathrm{gr} / \mathrm{cm}^{3}-0,70 \mathrm{gr} / \mathrm{cm}^{3}$ tergantung umur kayu dan komposisi kimia dr kayu tersebut. Komponen kimia seperti ekstraktif dan lignin di dalam kayu diperkirakan akan menambah kenaikan massa jenis kayu. (Cassey, 1980)

\subsection{Eucalyptus $S p$}

Tanaman Eucalyptus spp. Merupakan family dari Myrtaceae, marga Eucalyptus dengan jenis Eucalyptus spp. Keluarga Myrtaceae terdiri dari 500 jeni, 138 varietas dan merupakan tumbuhan endemic di Australia dan kepulauan sebelah utara, Irian dan Philipina. Nama Eucalyptus Urophylla diberi oleh Dr. Blake. Nama Urophylla berasal dari 4unani 4unani yaitu auro yang berarti ekor dan phylla berarti daun. (Purba, 1999). Hampir semua jenis Eucalyptus sp dapat beradaptasi pada berbagai iklim. Bahkan tumbuhan ini pun dapat bertahan di lingkungan yang kering dan dapat beradaptasi pada habitat hutan dataran rendah. Eucalyptus ini juga dapat tumbuh pada lingkungan tanah yang dangkal, rawa-rawa, lahan gambut. Yang secara periodik digenangi air 


\section{JVTI}

JURNAL VOKASI

\section{Research Paper Vol 2, No 2, Tahun 2020}

dengan variasi kesuburan tanah mulai dari tanah gersang sampai tanah yang baik dan subur. (Osloria Sihite, 2008)

Tabel 3. Komponen kimia kayu eucalyptus

\begin{tabular}{|l|c|}
\hline \multicolumn{1}{|c|}{ Sifat Kimia Kayu } & Eucalyptus Hybrid \\
\hline Lignin (\%) & 24,03 \\
Selulosa Alfa (\%) & 50,84 \\
Kelarutan Air Dingin (\%) & - \\
Kelarutan Air Panas (\%) & 1,45 \\
Kelarutan NaOH 1\% (\%) & 2,19 \\
Kadar Abu (\%) & 21,33 \\
Ekstraktif (\%) & 0,39 \\
& \\
\hline
\end{tabular}

Sumber: Han Roliadi, dkk (2010)

Tabel 4. Morfologi serat kayu eucalyptus

\begin{tabular}{|l|l|}
\hline $\begin{array}{l}\text { Sifat Fisik dan } \\
\text { Morfologi }\end{array}$ & Eucalyptus Hybrid \\
\hline Panjang Serat $(\mathrm{mm})$ & 1,26 \\
Diameter Serat $(\mu)$ & 25,69 \\
Rungkle Ratio & 0,17 \\
Felting Ratio & 46,40 \\
Fleksibility Ratio & 0,82 \\
Coef. Rigidity & 0,0872 \\
\hline
\end{tabular}

Sumber: Han Roliadi, dkk (2010)

Bulk density adalah parameter sederhana dan langsung, karena banyak digunakan oleh industri pulp, hal tersebut berkaitan dengan massa jenis tumpukan serpihan dan massa jenis dasar kayu. Nilai-nilai dasar dan bulk density yang diperoleh untuk eucalyptus dan pinus konsisten dengan yang ditemukan dalam literatur. Berbagai klon komersial eucalyptus yang berbeda ditemukan basic density dalam kisaran $0,46 \mathrm{gr} / \mathrm{cm}^{3}-0,51$ $\mathrm{gr} / \mathrm{cm}^{3}$. (Gomide, et.al, 2005)

Dalam penelitian Ignatius K.A menyatakan rata-rata basic density yang serupa untuk $E$. Grandis dan E. Urophylla dilaporkan juga oleh Couto et al. (2013) yakni berturut-turut sebesar $0.48 \mathrm{gr} / \mathrm{cm}^{3}$ dan $0.52 \mathrm{gr} / \mathrm{cm}^{3}$ yang merupakan rata-rata dari tegakan klon berumur 42 dan 54 bulan yang ditanam di hutan tanaman di Minas Gerasi Brazil. Sedangkan rata-rata basic density yang relatif lebih besar dilaporkan oleh da Silva Poubel et al. (2011) sebesar $0.57 \mathrm{gr} / \mathrm{cm}^{3}$ pada $E$. Pellita berumur 15 tahun yang ditanam di Rio de Janiero, Brazil.

\section{Bahan dan Metode}

Penelitian ini dilakukan dengan percobaan menggunakan digester mini skala laboratorium dengan jenis rotary digester berjumlah 4 vessel, masing-masing vessel mempunyai kapasitas maksimal 150 gr OD. Pemasakan ini dilakukan dengan metode kraft pulping. Alkali Aktive charge yang ditambahkan yaitu $18 \%$, rasio larutan pemasak 4/1 dengan perlakuan pemasakan selama 90 menit +180 menit.

Bahan baku chip berasal dari woodhandling plant di PT OKI Pulp and Paper. Penelitian ini menggunakan 3 bahan baku yang berbeda, ketiga jenis bahan baku tersebut yaitu Acacia crassicarpa, Acacia mangium dan Eucalyptus. Dari ketiga bahan baku tersebut akan dilakukan pencampuran agar mendapatkan hasil yang sesuai dengan parameter target yang telah ditentukan. Parameter-parameter yang di ukur untuk pulp coklat yaitu kappa number, viskositas, yield, total solid black liquor, residual alkali, brightness dan reject. Standar pabrik yang ditentukan untuk kappa yaitu $20-23$, viskositas $>1100 \mathrm{~cm}^{3} / \mathrm{gr}$, yield 50-60\%, TS 15-17, REA 6-10 g/l as $\mathrm{Na}_{2} \mathrm{O}$, reject $<1 \%$ dan brightness $>28 \%$ ISO.

Alat dan bahan yang digunakan antara lain: mini digester, screen, gelas beker, gelas ukur, dehydrator, oven, timbangan, cawan, pipet, labu ukur, mess ukuran 35\&80, viskometer oswald, agitator, white liquor dan air demin.

\subsection{Variasi penelitian}

Tabel 5. Variasi pertama/blank

\begin{tabular}{|c|c|c|c|c|}
\hline \multirow{2}{*}{ Bahan Baku } & \multicolumn{4}{|c|}{ Rasio } \\
\cline { 2 - 5 } & 1 & 2 & 3 & 4 \\
\hline $\begin{array}{c}\text { Acacia } \\
\text { crassicarpa }\end{array}$ & $100 \%$ & $0 \%$ & $0 \%$ & $0 \%$ \\
\hline Acacia mangium & $0 \%$ & $100 \%$ & $0 \%$ & $0 \%$ \\
\hline Eucalyptus & $0 \%$ & $0 \%$ & $100 \%$ & $0 \%$ \\
\hline
\end{tabular}

Tabel 6. Variasi kedua

\begin{tabular}{|c|c|c|c|c|}
\hline \multirow{2}{*}{ Bahan Baku } & \multicolumn{4}{|c|}{ Rasio } \\
\cline { 2 - 5 } & 1 & 2 & 3 & 4 \\
\hline $\begin{array}{c}\text { Acacia } \\
\text { crassicarpa }\end{array}$ & $50 \%$ & $60 \%$ & $70 \%$ & $80 \%$ \\
\hline Acacia mangium & $50 \%$ & $40 \%$ & $30 \%$ & $20 \%$ \\
\hline Eucalyptus & $0 \%$ & $0 \%$ & $0 \%$ & $0 \%$ \\
\hline
\end{tabular}

Tabel 7. Variasi ketiga

\begin{tabular}{|c|c|c|c|c|}
\hline \multirow{2}{*}{ Bahan Baku } & \multicolumn{4}{|c|}{ Rasio } \\
\cline { 2 - 5 } & 1 & 2 & 3 & 4 \\
\hline Acacia mangium & $50 \%$ & $60 \%$ & $70 \%$ & $80 \%$ \\
\hline Eucalyptus & $50 \%$ & $40 \%$ & $30 \%$ & $20 \%$ \\
\hline
\end{tabular}




\section{JVTI}

JURNAL VOKASI

\section{Research Paper Vol 2, No 2, Tahun 2020}

\begin{tabular}{|c|c|c|c|c|}
\hline $\begin{array}{c}\text { Acacia } \\
\text { crassicarpa }\end{array}$ & $0 \%$ & $0 \%$ & $0 \%$ & $0 \%$ \\
\hline
\end{tabular}

Tabel 8. Variasi keempat

\begin{tabular}{|c|c|c|c|c|}
\hline \multirow{2}{*}{ Bahan Baku } & \multicolumn{4}{|c|}{ Rasio } \\
\cline { 2 - 5 } & 1 & 2 & 3 & 4 \\
\hline $\begin{array}{c}\text { Acacia } \\
\text { crassicarpa }\end{array}$ & $50 \%$ & $60 \%$ & $70 \%$ & $80 \%$ \\
\hline Eucalyptus & $50 \%$ & $40 \%$ & $30 \%$ & $20 \%$ \\
\hline Acacia mangium & $0 \%$ & $0 \%$ & $0 \%$ & $0 \%$ \\
\hline
\end{tabular}

Tabel 9. Variasi kelima

\begin{tabular}{|c|c|c|c|c|}
\hline \multirow{2}{*}{ Bahan Baku } & \multicolumn{4}{|c|}{ Rasio } \\
\cline { 2 - 5 } & 1 & 2 & 3 & 4 \\
\hline Acacia mangium & $70 \%$ & $20 \%$ & $0 \%$ & $0 \%$ \\
\hline $\begin{array}{c}\text { Acacia } \\
\text { crassicarpa }\end{array}$ & $20 \%$ & $70 \%$ & $0 \%$ & $0 \%$ \\
\hline Eucalyptus & $10 \%$ & $10 \%$ & $0 \%$ & $0 \%$ \\
\hline
\end{tabular}

Tabel 10. Variasi keenam

\begin{tabular}{|c|c|c|c|c|}
\hline \multirow{2}{*}{ Bahan Baku } & \multicolumn{4}{|c|}{ Rasio } \\
\cline { 2 - 5 } & 1 & 2 & 3 & 4 \\
\hline Acacia mangium & $70 \%$ & $10 \%$ & $0 \%$ & $0 \%$ \\
\hline $\begin{array}{c}\text { Acacia } \\
\text { crassicarpa }\end{array}$ & $10 \%$ & $70 \%$ & $0 \%$ & $0 \%$ \\
\hline Eucalyptus & $20 \%$ & $20 \%$ & $0 \%$ & $0 \%$ \\
\hline
\end{tabular}

\section{Hasil dan pembahasan}

\subsection{Pengaruh rasio bahan baku terhadap} kappa number

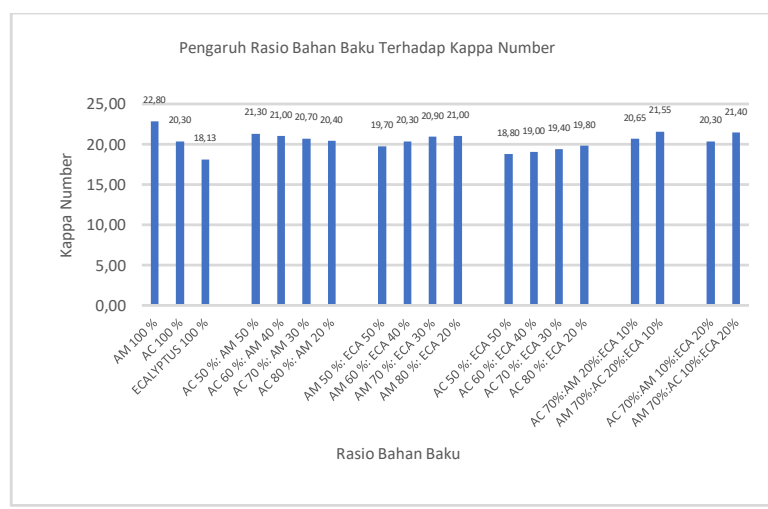

Gambar 5. Grafik pengaruh rasio bahan baku terhadap kappa number

Kappa number merupakan pengujian kimia yang diperlakukan terhadap pulp untuk menentukan tingkat delignifikasi, kekuatan relatif dari pulp dan kesanggupan untuk diputihkan. Kappa number didefinisikan sebagai jumlah konsumsi permanganat dalam sampel pulp yang mengandung lignin yang belum bereaksi. Setelah beberapa waktu, permanganat bereaksi dengan pulp yang ditentukan dengan metode titrasi. Kappa number kemudian ditentukan dengan jumlah $0,1 \mathrm{~N}$ larutan $\mathrm{KMnO}_{4}$ yang dikonsumsi oleh 1 gr pulp dalam waktu 10 menit dengan suhu $25{ }^{\circ} \mathrm{C}$. Kappa number ini sangat berguna untuk menentukan kadar lignin dalam pulp.

Untuk variasi $100 \%$ Acacia mangium, Acacia crassicarpa dan Eucalyptus digunakan sebagai variasi pertama acuan blank untuk perbandingan nilai dengan variasi lainnya, didapatkan nilai kappa number yang paling tinggi yaitu Acacia mangium dan nilai terendah Eucalyptus. Pada variasi kedua yaitu Acacia crassicarpa dan Acacia mangium berturut-turut dengan rasio 50:50;60:40;70:30;80:20. Didapatkan hasil kappa number yang paling tinggi yaitu variasi rasio 50:50 dengan nilai kappa 21,30. Pada variasi ketiga yaitu Acacia mangium dan Eucalyptus berturut-turut dengan rasio 50:50;60:40;70:30;80:20. Didapatkan hasil kappa number yang paling tinggi yaitu variasi 80:20 dengan nilai kappa 21,00. Pada variasi keempat yaitu Acacia crassicarpa dan Eucalyptus berturutturut dengan rasio 50:50;60:40;70:30;80:20. Didapatkan hasil kappa number yang paling tinggi yaitu variasi 80:20 dengan nilai kappa 19,80. Pada variasi kelima terdapat 3 bahan baku yang dilakukan pencampuran yaitu Acacia crassicarpa, Acacia mangium dan Eucalyptus berturut-turut dengan rasio 70:20:10 dan 20:70:10. Didapatkan hasil kappa number yang paling tinggi yaitu variasi rasio 20:70:10 dengan nilai kappa number 21,55. Pada variasi keenam terdapat 3 bahan baku yang dilakukan pencampuran yaitu Acacia crassicarpa, Acacia mangium dan Eucalyptus berturut-turut dengan rasio 70:10:20 dan 10:70:20. Didapatkan hasil kappa number yang paling tinggi yaitu variasi rasio 10:70:20 dengan nilai kappa 21,40.

\subsection{Pengaruh rasio bahan baku terhadap viskositas}

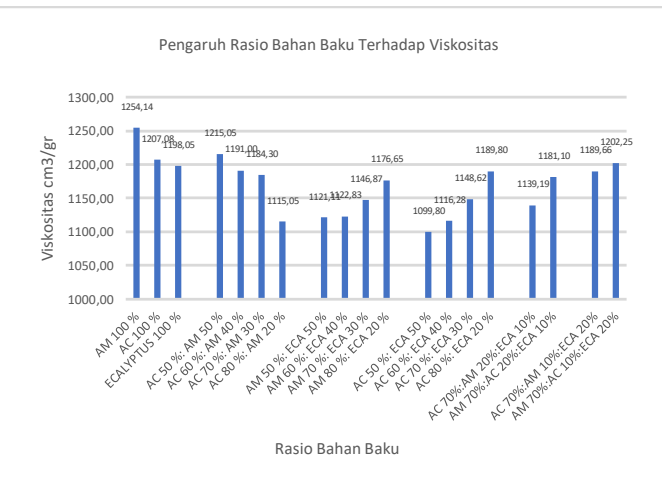




\section{JVTI}

JURNAL VOKASI

\section{Research Paper Vol 2, No 2, Tahun 2020} Gambar 6. Grafik pengaruh rasio bahan baku terhadap
viskositas

Viskositas secara umum memiliki nilai yang berbeda-beda tergantung pada jenis cairan dan suhu. Cairan mempunyai viskositas lebih besar daripada gas, karena mempunyai gaya gesek untuk mengalir lebih besar. Pada kebanyakan cairan viskositasnya turun dengan naiknya suhu. Sebaliknya viskositas akan naik dengan turunnya suhu. Viskositas naik dengan bertambahnya tekanan. Sebaliknya viskositas cairan turun dengan berkurangnya tekanan. Untuk larutan viskositasnya bergantung pada konsentrasi atau kepekatan larutan. Umumnya larutan yang konsentrasinya tinggi, viskositasnya juga tinggi. Sebaliknya, larutan yang konsentrasinya rendah viskositasnya juga akan rendah (Yazid,E. 2005). Sedangkan pada penelitian ini viskositas menunjukkan nilai derajat polimerisasi selulosa pulp hasil dari proses delignifikasi. Derajat polimerisai menyatakan panjang rantai unit kimia yang berulang, jadi semakin panjang derajat polimerisasi maka rantai gugus selulosa semakin panjang.

Untuk variasi $100 \%$ Acacia mangium, Acacia crassicarpa dan Eucalyptus digunakan sebagai variasi pertama acuan blank untuk perbandingan nilai dengan variasi lainnya, didapatkan nilai viskositas yang paling tinggi yaitu mangium dan nilai terendah Eucalyptus. Pada variasi kedua yaitu Acacia crassicarpa dan Acacia mangium berturut-turut dengan rasio 50:50;60:40;70:30;80:20. Didapatkan nilai viskositas yang paling tinggi yaitu variasi rasio 50:50 dengan nilai viskositas $1215,05 \mathrm{~cm}^{3} / \mathrm{g}$. Pada variasi ketiga yaitu Acacia mangium dan Eucalyptus berturut-turut dengan rasio 50:50;60:40;70:30;80:20. Didapatkan nilai viskositas yang paling tinggi yaitu variasi 80:20 dengan nilai viskositas $1176,65 \mathrm{~cm}^{3} / \mathrm{gr}$. Pada variasi keempat yaitu Acacia crassicarpa dan Eucalyptus berturut-turut dengan rasio 50:50;60:40;70:30;80:20. Didapatkan nilai viskositas yang paling tinggi yaitu variasi 80:20 dengan nilai viskositas $1189,80 \mathrm{~cm}^{3} / \mathrm{gr}$. Pada variasi kelima terdapat 3 bahan baku yang dilakukan pencampuran yaitu Acacia crassicarpa, Acacia mangium dan Eucalyptus berturut-turut dengan rasio 70:20:10 dan 20:70:10. Didapatkan nilai viskositas yang paling tinggi yaitu variasi rasio 20:70:10 dengan nilai $1181,10 \mathrm{~cm}^{3} /$ gr. Pada variasi keenam terdapat 3 bahan baku yang dilakukan pencampuran yaitu Acacia crassicarpa, Acacia mangium dan Eucalyptus berturut-turut dengan rasio 70:10:20 dan 10:70:20. Didapatkan nilai viskositas yang paling tinggi yaitu variasi rasio 10:70:20 dengan nilai viskositas 1202,25 $\mathrm{cm}^{3} / \mathrm{gr}$.

\subsection{Pengaruh rasio bahan baku terhadap yield}

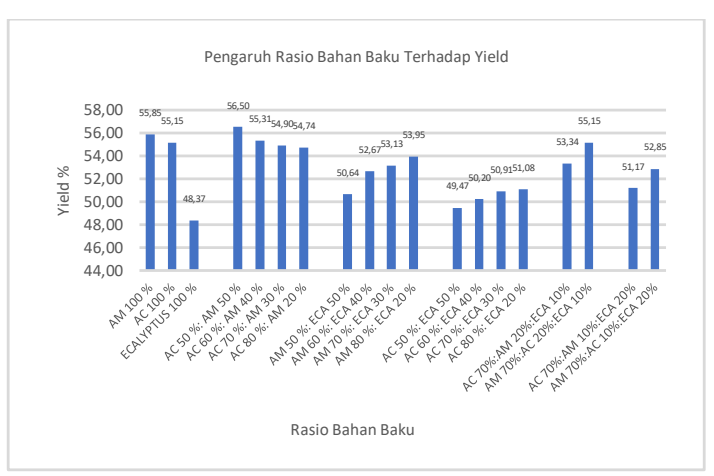

Gambar 7. Grafik pengaruh rasio bahan baku terhadap yield

Yield adalah jumlah massa chip kayu yang menjadi serat yang terpisah satu sama lain di karnakan adanya proses pemasakan dengan bantuan temperatur dan bahan kimia alkali $\mathrm{NaOH}$ dan $\mathrm{Na}_{2} \mathrm{~S}$. Dalam kandungan kayu terdapat beberapa komponen penyusun kayu seperti selulosa, hemiselulosa dan lignin. Tujuan dari proses pemasakan yaitu untuk mendegradasi lignin yang berfungsi mengikat gugus selulosa yang terdapat pada struktur kayu.

Untuk variasi $100 \%$ Acacia mangium, Acacia crassicarpa dan Eucalyptus di gunakan sebagai variasi pertama acuan blank untuk perbandingan nilai dengan variasi lainnya, didapatkan nilai yield yang paling tinggi yaitu Acacia mangium dan nilai terendah Eucalyptus. Pada variasi kedua yaitu Acacia crassicarpa dan Acacia mangium berturut-turut dengan rasio 50:50;60:40;70:30;80:20. Didapatkan hasil yield yang paling tinggi yaitu variasi rasio 50:50 dengan nilai yield 56,50\%. Pada variasi ketiga yaitu Acacia mangium dan Eucalyptus berturutturut dengan rasio 50:50;60:40;70:30;80:20. Didapatkan hasil yield yang paling tinggi yaitu variasi 80:20 dengan nilai yield 53,95\%. Pada variasi keempat yaitu Acacia crassicarpa dan Eucalyptus berturut-turut dengan rasio 50:50;60:40;70:30;80:20. Didapatkan hasil yield yang paling tinggi yaitu variasi 80:20 dengan nilai yield 51,08\%. Pada variasi kelima terdapat 3 bahan baku yang dilakukan pencampuran yaitu Acacia crassicarpa, Acacia mangium dan Eucalyptus berturut-turut dengan rasio 70:20:10 dan 20:70:10. Didapatkan hasil yield yang paling tinggi yaitu variasi rasio 20:70:10 dengan nilai yield $55,15 \%$. Pada variasi keenam terdapat 3 bahan baku yang dilakukan pencampuran yaitu 


\section{JVTI}

JURNAL VOKASI

TEKNOLOGI INDUSTRI

\section{Research Paper Vol 2, No 2, Tahun 2020}

Acacia crassicarpa, Acacia mangium dan Eucalyptus berturut-turut dengan rasio 70:10:20 dan 10:70:20. Didapatkan hasil yield yang paling tinggi yaitu variasi rasio 10:70:20 dengan nilai yield $52,85 \%$.

\subsection{Pengaruh rasio bahan baku terhadap total solid}

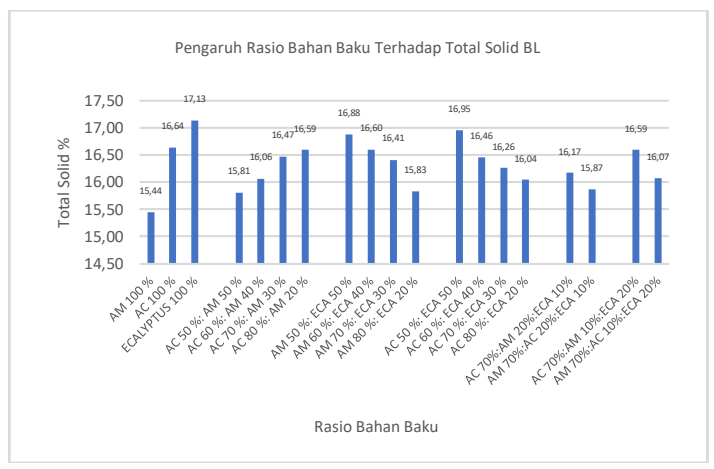

Gambar 8. Grafik pengaruh rasio bahan baku terhadap total solid

Black liquor adalah cairan sisa hasil pemasakan pada proses kraft pulping. Lignin merupakan komponen terbesar yang terdapat dalam larutan sisa pemasak pulp atau lindi hitam. Lignin yang terkandung dalam lindi hitam kraft kayu lunak sekitar $46 \%$ dari padatan kering (Sjostrom, 1995). Senyawa organik dalam lindi hitam biasanya digunakan sebagai bahan bakar dan senyawa anorganiknya diambil kembali. Dengan pertimbangkan kandungan Total Solid (TS) yang merupakan zat padat total/residu total setelah sampel dikeringkan pada suhu $105^{\circ} \mathrm{C}$. Menurut Sjostrom (1995), lindi hitam merupakan campuran yang sangat kompleks yang mengandung sejumlah besar komponen dengan struktur dan susunan yang berbeda. Bahan organik dalam lindi hitam yang dihasilkan setelah pembuatan pulp pada dasarnya terdiri dari lignin dan produk-produk degradasi karbohidrat di samping bagian-bagian kecil ekstraktif dan produk-produk reaksinya.

Pada grafik di atas untuk variasi $100 \%$ Acacia mangium, Acacia crassicarpa dan Eucalyptus di gunakan sebagai variasi pertama acuan blank untuk perbandingan nilai dengan variasi lainnya, didapatkan nilai $T S$ yang paling tinggi yaitu Eucalyptus dan nilai terendah Acacia mangium. Pada variasi kedua yaitu Acacia crassicarpa dan Acacia mangium berturut-turut dengan rasio 50:50;60:40;70:30;80:20. Didapatkan nilai TS yang paling tinggi yaitu variasi rasio 80:20 dengan nilai $T S 16,59 \%$. Pada variasi ketiga yaitu
Acacia mangium dan Eucalyptus berturut-turut dengan rasio 50:50;60:40;70:30;80:20. Didapatkan nilai $T S$ yang paling tinggi yaitu variasi 50:50 dengan nilai TS 16,88\%. Pada variasi keempat yaitu Acacia crassicarpa dan Eucalyptus berturut-turut dengan rasio 50:50;60:40;70:30;80:20. Didapatkan nilai TS yang paling tinggi yaitu variasi 50:50 dengan nilai TS 16,95\% Pada variasi kelima terdapat 3 bahan baku yang dilakukan pencampuran yaitu Acacia crassicarpa, Acacia mangium dan Eucalyptus berturut-turut dengan rasio 70:20:10 dan 20:70:10. Didapatkan nilai $T S$ yang paling tinggi yaitu variasi rasio 70:20:10 dengan nilai $T S$ $16,59 \%$. Pada variasi keenam terdapat 3 bahan baku yang dilakukan pencampuran yaitu Acacia crassicarpa, Acacia mangium dan Eucalyptus berturut-turut dengan rasio 70:10:20 dan 10:70:20. Didapatkan nilai $T S$ yang paling tinggi yaitu variasi rasio 70:10:20 dengan nilai Yield $16,59 \%$.

\subsection{Pengaruh rasio bahan baku terhadap $R E A$}

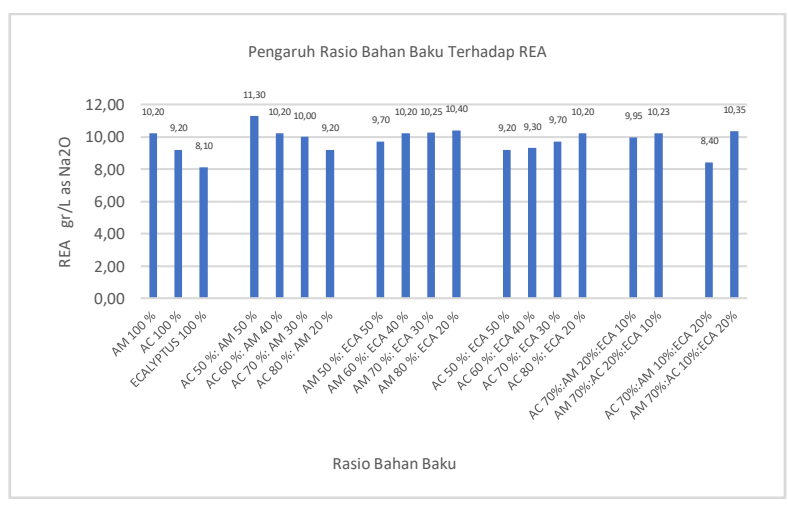

Gambar 9. Grafik pengaruh rasio bahan baku terhadap

\section{REA}

REA atau residual effective alkali digunakan untuk menyatakan kandungan alkali sisa yang masih terdapat dalam black liquor setelah proses pemasakan di digester maupun setelah proses impregnasi di impregnation bin. REA penting diketahui untuk memastikan bahwa konsentrasi alkali pada tahap akhir pemasakan masih cukup untuk mencegah terjadinya kondensasi lignin selama proses pemasakan berlangsung. Kondisi akhir reaksi harus dijaga tetap alkali (basa) karena lignin hanya larut dalam alkali kuat $(\mathrm{pH}>12)$ dan jika kondisi akhir tidak cukup alkali $(\mathrm{pH}<11)$ maka lignin akan membentuk aglomerat dari molekul-molekul yang sudah terpotong menjadi molekul baru yaitu lignin presipitat (kondensasi lignin). Hal ini menyebabkan lignin sulit untuk didegradasi kembali sehingga alkali aktif akan 


\section{JVTI}

JURNAL VOKASI

TEKNOLOGI INDUSTRI

\section{Research Paper Vol 2, No 2, Tahun 2020}

beralih menyerang gugus-gugus karbohidrat sehingga viskositas pulp menjadi rendah namun kappa number tetap tinggi. (Hendro, dan Tampubolon, D.P., 2011). Menurut Biermann (1996) alkali efektif yang tersisa didalam larutan pemasak saat pemasakan selesai disebut residual alkali. Level residual alkali menentukan $\mathrm{pH}$ akhir cairan. Pada $\mathrm{pH}$ sekitar 12, beberapa hemiselulosa dalam cairan bisa terdeposit di dalam serat dengan sedikit peningkatan rendemen. Jika $\mathrm{pH}$ turun terlalu di bawah 12, lignin bisa terdeposit pada pulp sehingga meningkatkan kappa number, bahan kimia pemutihan, penurunan ikatan pada pulp tanpa pemutihan, serta timbul kerak.

Untuk variasi $100 \%$ Acacia mangium, Acacia crassicarpa dan Eucalyptus di gunakan sebagai variasi pertama acuan blank untuk perbandingan nilai dengan variasi lainnya, didapatkan nilai $R E A$ yang paling tinggi yaitu Acacia mangium dan nilai terendah Eucalyptus. Pada variasi kedua yaitu Acacia crassicarpa dan Acacia mangium berturut-turut dengan rasio 50:50;60:40;70:30;80:20. Didapatkan nilai $R E A$ yang paling tinggi yaitu variasi rasio 50:50 dengan nilai $R E A \quad 11,30 \mathrm{~g} / \mathrm{l}$ as $\mathrm{Na}_{2} \mathrm{O}$. Pada variasi ketiga yaitu Acacia mangium dan Eucalyptus berturut-turut dengan rasio 50:50;60:40;70:30;80:20. Didapatkan nilai REA yang paling tinggi yaitu variasi 80:20 dengan nilai REA $10,4 \mathrm{~g} / \mathrm{l}$ as $\mathrm{Na}_{2} \mathrm{O}$. Pada variasi keempat yaitu Acacia crassicarpa dan Eucalyptus berturut-turut dengan rasio 50:50;60:40;70:30;80:20. Didapatkan nilai $R E A$ yang paling tinggi yaitu variasi 80:20 dengan nilai REA 10,2 g/l as $\mathrm{Na}_{2} \mathrm{O}$. Pada variasi kelima terdapat 3 bahan baku yang dilakukan pencampuran yaitu Acacia crassicarpa, Acacia mangium dan Eucalyptus berturut-turut dengan rasio 70:20:10 dan 20:70:10. Didapatkan nilai $R E A$ yang paling tinggi yaitu variasi rasio 20:70:10 dengan nilai REA 10,23 g/l as $\mathrm{Na}_{2} \mathrm{O}$. Pada variasi keenam terdapat 3 bahan baku yang dilakukan pencampuran yaitu Acacia crassicarpa, Acacia mangium dan Eucalyptus berturut-turut dengan rasio 70:10:20 dan 10:70:20. Didapatkan nilai $R E A$ yang paling tinggi yaitu variasi rasio 10:70:20 dengan REA 10,35 g/l as $\mathrm{Na}_{2} \mathrm{O}$.

\subsection{Pengaruh rasio bahan baku terhadap brightness}

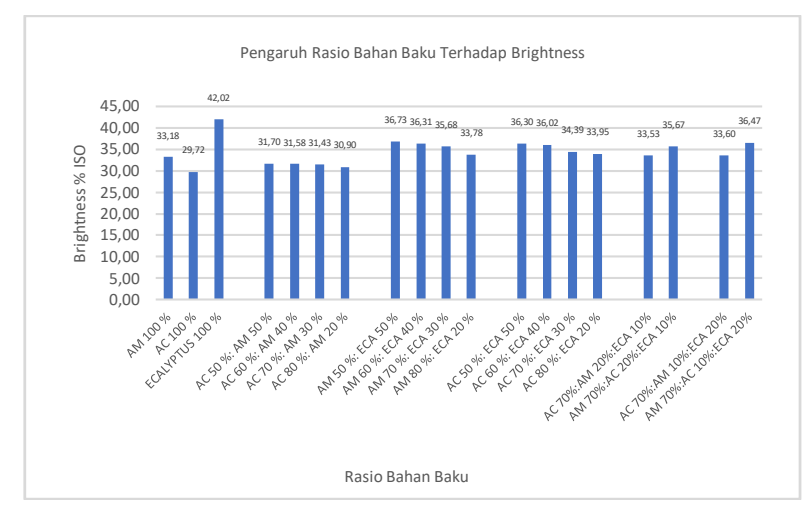

Gambar 10. Grafik pengaruh rasio bahan baku terhadap brightness

Brightness adalah sifat lembaran pulp untuk memantulkan cahaya yang diukur pada suatu kondisi yang baku, digunakan sebagai indikasi tingkat keputihan. Keputihan pulp diukur dengan kemampuannya memantulkan cahaya monokromatik dan diperbandingkan dengan standar yang telah diketahui yang dinyatakan dalam \%ISO atau \%GE (Sirait, 2003). Tingkat kecerahan (brightness) pulp tergantung pada jenis dan jumlah bahan kimia pemutih yang digunakan pada tahap bleaching. Bilangan kappa yang kecil akan diikuti dengan tingkat kecerahan yang meningkat. Pada penelitian ini tidak dilakukan proses pemutihan, sehingga brightness yang dihasilkan murni dari pigmen dan karakteristik dari masing-masing kayu yang digunakan.

Untuk variasi 100\% Acacia mangium, Acacia crassicarpa dan Eucalyptus di gunakan sebagai variasi pertama acuan blank untuk perbandingan nilai dengan variasi lainnya, didapatkan nilai brightness yang paling tinggi yaitu Eucalyptus dan nilai brightness terendah yaitu Acacia crassicarpa. Pada variasi kedua yaitu Acacia crassicarpa dan Acacia mangium berturut-turut dengan rasio 50:50;60:40;70:30;80:20. Didapatkan hasil brightness yang paling tinggi yaitu variasi rasio 50:50 dengan nilai 31,70\% ISO. Pada variasi ketiga yaitu Acacia mangium dan Eucalyptus berturut-turut dengan rasio 50:50;60:40;70:30;80:20. Didapatkan hasil brightness yang paling tinggi yaitu variasi 50:50 dengan nilai 36,73 \% ISO. Pada variasi keempat yaitu Acacia crassicarpa dan Eucalyptus berturutturut dengan rasio 50:50;60:40;70:30;80:20. Didapatkan hasil brightness yang paling tinggi yaitu variasi 50:50 dengan nilai 36,30 \% ISO. Pada variasi kelima terdapat 3 bahan baku yang dilakukan pencampuran yaitu Acacia crassicarpa, Acacia mangium dan Eucalyptus berturut-turut dengan rasio 70:20:10 dan 20:70:10. Didapatkan hasil brightness yang paling tinggi yaitu variasi 


\section{JVTI}

JURNAL VOKASI

TEKNOLOGI INDUSTRI

\section{Research Paper Vol 2, No 2, Tahun 2020}

rasio 20:70:10 dengan nilai 35,67 \% ISO. Pada variasi keenam terdapat 3 bahan baku yang dilakukan pencampuran yaitu Acacia crassicarpa, Acacia mangium dan Eucalyptus berturut-turut dengan rasio 70:10:20 dan 10:70:20. Didapatkan hasil brightness yang paling tinggi yaitu variasi rasio 10:70:20 dengan nilai $36,47 \%$ ISO.

\subsection{Pengaruh rasio bahan baku terhadap reject}

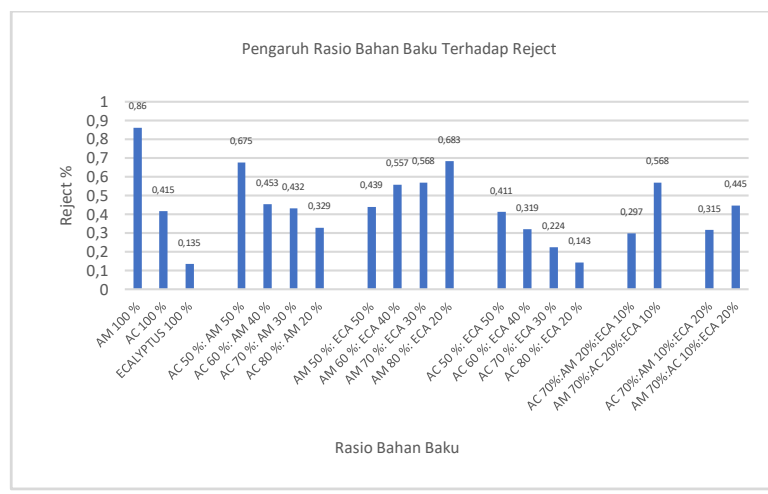

Gambar 11. Grafik pengaruh rasio bahan baku terhadap reject

Reject adalah chip kayu yang tidak menjadi individual fiber setelah proses pemasakan sehingga masih banyak ada sebagian dari chip yang masih menggumpal satu sama lainnya. Hal ini terjadi karena proses pemasakan yang tidak berjalan dengan optimal sehingga ketika sudah menjadi pulp masih banyak komponen kayu atau knot yang tidak hancur dalam proses pemasakan.

Untuk variasi $100 \%$ Acacia mangium, Acacia crassicarpa dan Eucalyptus di gunakan sebagai variasi pertama acuan blank untuk perbandingan nilai dengan variasi lainnya, didapatkan nilai reject yang paling tinggi yaitu Acacia mangium dan nilai reject terendah yaitu Eucalyptus. Pada variasi kedua yaitu Acacia crassicarpa dan Acacia mangium berturut-turut dengan rasio 50:50;60:40;70:30;80:20. Didapatkan hasil reject yang paling tinggi yaitu variasi rasio 50:50 dengan nilai $0,675 \%$. Pada variasi ketiga yaitu Acacia mangium dan Eucalyptus berturut-turut dengan rasio 50:50;60:40;70:30;80:20. Didapatkan hasil reject yang paling tinggi yaitu variasi 80:20 dengan nilai 0,683\%. Pada variasi keempat yaitu Acacia crassicarpa dan Eucalyptus berturut-turut dengan rasio 50:50;60:40;70:30;80:20. Didapatkan hasil reject yang paling tinggi yaitu variasi 50:50 dengan nilai $0,411 \%$. Pada variasi kelima terdapat 3 bahan baku yang dilakukan pencampuran yaitu Acacia crassicarpa, Acacia mangium dan Eucalyptus berturut-turut dengan rasio 70:20:10 dan
20:70:10. Didapatkan hasil reject yang paling tinggi yaitu variasi rasio 20:70:10 dengan nilai $0,658 \%$. Pada variasi keenam terdapat 3 bahan baku yang dilakukan pencampuran yaitu Acacia crassicarpa, Acacia mangium dan Eucalyptus berturut-turut dengan rasio 70:10:20 dan 10:70:20. Didapatkan hasil reject yang paling tinggi yaitu variasi rasio 10:70:20 dengan nilai $0,455 \%$.

\subsection{Pembahasan keseluruhan}

Pada proses cooking pulp, indikator utama yang menjadi acuan berhasil tidaknya pemasakan yaitu kappa number serta di dukung dengan parameter-parameter lain yang juga berpengaruh terhadap kualitas pulp dan proses di lapangan. Sehingga kappa number menjadi sangat penting untuk selalu di kontrol pada proses pemasakan.

Pada gambar 5, 6, 7, 9, 11 ditunjukkan parameter kappa number, viskositas, yield, REA dan reject. Parameter-parameter tersebut berbanding lurus dengan nilai kappa number, jika nilai kappa number mengalami kenaikan maka parameter-parameter tersebut mengalami kenaikan. Dan sebaliknya, jika kappa number turun maka parameter-parameter tersebut akan mengalami penurunan. Dari grafik tersebut dapat dilihat ada kenaikan dan penurunan kappa number, yield, REA, reject dan viskositas pulp. Kappa number mengindikasikan banyaknya kandungan lignin yang tersisa di dalam pulp. Yield mengindikasikan seberapa banyak chip yang dapat terkonversi menjadi buburan pulp dalam persen. Jika nilai kappa number mengalami kenaikan maka yield juga mengalami kenaikan yang disebabkan masih adanya chip yang belum matang sempurna sehingga berat daripada pulp akan meningkat. REA menunjukkan nilai sisa efektif alkali yang masih tersisa di dalam black liquor. Jika kappa number mengalami kenaikan REA akan mengalami kenaikan yang berarti sisa efektif alkali tidak ter-penetrasi dengan sempurna ke dalam chip sehingga menyebabkan kenaikan pada kappa number. Reject mengindikasikan banyaknya chip yang tidak menjadi buburan pulp. Jika nilai kappa number mengalami kenaikan maka reject pun mengalami kenaikan, yang berarti ada sebagian dari chip pada proses pemasakan tidak matang dengan sempurna. Sedangkan viskositas merupakan indikasi banyaknya rantai polimer selulosa yang masih utuh atau tersambung satu dengan lainnya. Dikarenakan proses awal pemasakan masih menyisakan lignin maka rantai selulosa masih ada yang berikatan dengan lignin sehingga viskositas juga akan naik. 


\section{JVTI}

JURNAL VOKASI

TEKNOLOGI INDUSTRI

\section{Research Paper Vol 2, No 2, Tahun 2020}

Pada gambar 5, 8, 10 ditunjukkan parameter kappa number, total solid dan brightness. Parameter-parameter tersebut berbanding terbalik dengan nilai kappa number, jika nilai kappa number mengalami kenaikan maka parameterparameter tersebut mengalami penurunan. Dan sebaliknya, jika kappa number turun maka parameter-parameter tersebut akan mengalami kenaikan. Terkecuali pada nilai brightness karena dipengaruhi suatu faktor. Total solid mengindikasikan banyaknya solid atau padatan yang terkandung pada black liquor. Jika kappa number mengalami penurunan artinya proses peluruhan lignin berjalan dengan optimal sehingga menyebabkan zat yang terkandung didalam kayu seperti zat ekstraktif dan zat-zat lain juga mengalami peluruhan. Di karenakan hal ini maka solid akan mengalami peningkatan. Kappa number juga berpengaruh terhadap nilai brightness, jika kappa number tinggi maka nilai brightness akan rendah. Namun pada penelitian ini ada sebagian rasio tidak mengalami hal demikian. Dari karakteristik awal bahan baku masing-masing dapat dilihat pigmen warna chip kayu yang paling terang yaitu Eucalyptus kemudian Acacia mangium dan Acacia crassicarpa. Dan setelah dilakukan pemasakan ternyata karakteristik awal dari bahan baku dapat mempengaruhi brightness pulp coklat.

Di karnakan setiap kayu memiliki karakteristik masing-masing maka dapat mempengaruhi parameter uji yang ditentukan. Menurut Henriksson et al. (2009), sifat-sifat kayu yang berpengaruh dalam produksi pulp dan kertas adalah sifat fisika (berat jenis), sifat anatomi dan dimensi serat (panjang serat, tebal dinding sel, persentase serabut, jari-jari dan parenkim), serta sifat kimia kayu (kandungan selulosa, kandungan ekstraktif dan kandungan lignin). Massa jenis pada tanaman atau kayu dapat dipengaruhi oleh beberapa hal seperti umur tanaman, sifat genetis selnya (a) tebal dinding serat, (b) ukuran serat dan (c) jumlah serta tipe sel dari (a) dan (b). Tebal dinding dan sel pembuluh (vessels), merupakan faktor paling dominan yang dapat mempengaruhi massa jenis kayu, terutama pada kelompok Angisospermae jenis kayu daun lebar (hardwood). Massa jenis hardwood sangat berpengaruh terhadap kualitas serpih yang dihasilkan dan kebutuhan enerji pada saat penyerpihan. Semakin tinggi massa jenisnya maka kualitas keseragaman serpih akan berkurang dan energi yang digunakan lebih tinggi. (Kellomaki, 1998).

Yang mempengaruhi hasil dari parameterparameter tersebut yaitu kerapatan jenis kayu yang membuat penetrasi cairan pemasak dapat terhambat oleh kerapatan pada masing-masing jenis kayu. Kerapatan kayu mempengaruhi kekasaran dan distribusi serat pulp yang merupakan parameter sangat penting untuk menentukan penggunaan akhir pulp (Magaton et al., 2009). Selain itu, kerapatan juga memiliki pengaruh terhadap hasil pemasakan pulp dan konsumsi kayu. Sejauh ini, kerapatan merupakan karakteristik kayu yang paling signifikan sebagai pertimbangan bahan baku pulp dan kertas (Segura, Zanao, Santos, \& Silva Jr., 2012). Meskipun kadar kimia kayu mempengaruhi kualitas pulp dan kertas yang dihasilkan, namun nilai tersebut kadang diabaikan pada kayu yang memiliki nilai produktivitas tinggi. Rendeman pulp dan kerapatan kayu yang tinggi lebih disukai sebagai bahan baku pulp meskipun memiliki kadar ekstraktif dan lignin yang tinggi (Magaton et al., 2009). Kayu yang memiliki produktivitas pulp yang tinggi dan konsumsi kayu rendah, menjadi pertimbangan utama dalam pemilihan suatu jenis pohon untuk dijadikan bahan baku pulp dan kertas, mengingat peningkatan rendemen pulp dan kerapatan membutuhkan waktu yang lama dalam proses pemuliaan pohon dan peningkatan sifat-sifatnya. Menemukan jenis baru yang memiliki nilai produktivitas pulp yang tinggi lebih sulit daripada peningkatan kualitas pulp dan kertas yang memiliki kadar ekstraktif dan lignin yang tinggi bisa dilakukan perlakuan bahan kimia. Hal tersebut dapat dilihat dari sedikitnya jenis pilihan yang dijadikan bahan baku pulp dan kertas. (Nambiar \& Harwood, 2014b)

Berat jenis tinggi untuk pengolahan proses kimia mengakibatkan kualitas untuk kertas lebih rendah. Berat jenis merupakan salah satu sifat fisik kayu yang dipersyaratkan untuk tujuan bahan baku pulp dan kertas. Kayu yang memiliki $\mathrm{BJ}>0,7 \mathrm{gr} / \mathrm{cm}^{3}$ membutuhkan kondisi pemasakan yang lebih lama dibandingkan BJ 0,49-0,7 gr/ $\mathrm{cm}^{3}$. (Pasaribu dan Tampubolon, 2007). Kayu yang memiliki BJ dan kadar lignin yang tinggi serta selulosa yang rendah, akan menghasilkan kualitas yang rendah dan waktu pengolahan menjadi lebih lama (Siagian, dkk., 1995)

Kerapatan/densitas kayu jenis Akasia berkisar 0,55 $\mathrm{gr} / \mathrm{cm}^{3}-0,70 \mathrm{gr} / \mathrm{cm}^{3}$, sedangkan jenis Eucalyptus yaitu berkisar $0,46 \mathrm{gr} / \mathrm{cm}^{3}-0,51$ $\mathrm{gr} / \mathrm{cm}^{3}$. Jadi semakin besar nilai density artinya semakin kuat dan semakin tinggi kerapatan dari kayu tersebut. Berat jenis kayu ditentukan oleh dinding sel dan kecilnya rongga sel yang membentuk pori-pori. Umur juga berpengaruh terhadap nilai kerapatan masing masing jenis kayu. Acacia mangium memiliki densitas yang lebih tinggi daripada Eucalyptus sehingga penetrasi cairan pemasak dapat terhambat jika perlakuan temperatur,waktu dan cairan pemasak 


\section{JVTI}

JURNAL VOKASI

\section{Research Paper Vol 2, No 2, Tahun 2020}

disamakan pada proses pemasakan. Rasio Acacia mangium menyebabkan kenaikan kappa number sedangkan rasio Eucalyptus menyebabkan penurunan kappa number. Begitu pula parameterparameter lainnya searah dengan kappa number dan berkebalikan dengan kappa number.

\section{Kesimpulan}

Setiap bahan baku memiliki karakteristik yang berbeda-beda sehingga menghasilkan kualitas yang berbeda-beda pula. Pada penelitian ini pengaruh densitas atau kerapatan dari Acacia mangium, Acacia crassicarpa dan Eucalyptus memiliki faktor penting yang membuat hasil pulp menjadi tidak sama. Kerapatan/densitas kayu jenis Acacia berkisar 0,55 $\mathrm{gr} / \mathrm{cm}^{3}-0,70 \mathrm{gr} / \mathrm{cm}^{3}$, sedangkan jenis Eucalyptus yaitu berkisar 0,46 $\mathrm{gr} / \mathrm{cm}^{3}-0,51 \mathrm{gr} / \mathrm{cm}^{3}$.

Rasio pencampuran bahan baku yang optimal pada penelitian ini yaitu dengan melihat parameter-parameter yang telah dibahas sebelumnya dengan melihat standar yang telah ditentukan pabrik. Standar untuk kappa yaitu 2023 , viskositas $>1100 \mathrm{~cm}^{3} / \mathrm{gr}$, yield $50-60 \%$, TS 15 17, REA 6-10 g/l as $\mathrm{Na}_{2} \mathrm{O}$, reject $<1 \%$ dan brightness $>28 \%$ ISO. Dari semua variasi yang dilakukan percobaan, di dapatkan yang paling optimal yaitu pada rasio AC 70\%:AM 20\%: ECA $10 \%$ yang memenuhi semua parameter yang ditentukan. Nilai parameter yang didapat yaitu kappa 20,65, viskositas $1139,19 \mathrm{~cm}^{3} / \mathrm{g}$, yield $53,34 \%$, total solid $16,59 \%$, REA $9,95 \mathrm{~g} / \mathrm{l}$ as as $\mathrm{Na}_{2} \mathrm{O}$, reject $0,297 \%$, brightness $33,53 \%$ ISO.

\section{Ucapan terima kasih}

Penulis mengucapkan terima kasih kepada PT OKI Pulp and Paper selaku pemberi fasilitas dalam penelitian ini. Terima kasih juga kepada departemen R\&D pulp PT OKI Pulp and paper, kepada pembimbing lapangan Bapak Ivan Widarko, kepada pembimbing tugas akhir Ibu Rachawati Apriani, S.T,M.T, kepada HRD bapak Indra Gunawan dan kepada teman-teman semua yang telah membantu penelitian ini.

\section{Daftar pustaka}

Bajpai, Pratima. 2018. Biermann's Handbook Of Pulp And Paper: Raw Material And Pulp Making(Third Edition). United States: Elsevier Inc

Cassey, J.P. 1980. Pulp and Paper Chemistry and Chemical Technology. Vol. 1, 3rd ed. Jhon Willey and son. New York

Direktorat Bina Produksi Kehutanan. 2010. Statistik Direktorat Jenderal Bina Kehutanan Tahun
2009. Dirjen Bina Kehutanan. Kementerian Kehutanan. Jakarta.

Dumanauw, J.F. 2001. Mengenal Kayu. Yogyakarta: Kanisius

Gomide, J.L.; Colodette, J.L.; Oliveira, R.C.; Silva, C.M. Caracterizacao tecnologica, para producao de celulose, da nova geracao de clones de eucalyptus do brasil. Revista Arvore 2005, 29(1), 129-137

Haroen, W.K., Uzair, Bahar, N. 1997. Kualitas Pulp Kertas Acacia Mangium Berbagai Umur Tanaman. Berita Selulosa. 4/Xxxiii.104-109.

Harsini, Tutuk Dan Susilowati. Pemanfaatan Kulit Buah Kakao Dari Limbah Perkebunan Kakao Sebagai Bahan Baku Pulp Dengan Proses Organosolv. Jurnal Ilmiah Teknik Lingkungan Vol.2 No. 2

Hendro, Tampubolon, D.P. 2011. Laporan Praktek Kerja Pabrik PT. Lontar Papyrus, Jambi. Akademi Teknologi Pulp Dan Kertas Bandung.

Henriksson G, Brannvall E \& Lennholm H. 2009. The Trees. Dalam : Pulp and Paper Chemistryand Technology Volume 1 Wood Chemistry and Wood Biotechnology. Ek M, Gellerstedt G, \& Henriksson. (Ed) Hlm. 13 - 44. Walter de Gryuter, Berlin.

Kartika, Wawan Haroen. 2006. Variabilitas Massa Jenis Kayu Daun Lebar Tropis terhadap Karakter Serat, Kimia dan Pulp Sulfat. Balai Besar Pulp dan Kertas BPPK. Bandung.

Kellomaki, S. 1998. Forest Resources and Sustainable Management. Paper Making and Technology.TAPPI.

Koray Gulsoy, Sergin Dan Saduman Tufek. 2013. Effect Of Chip Mixing Ratio Of Pinus Pinaster And Populus Tremula On Kraft Pulp And Paper Properties. Industrial And Engineering And Chemistry Research.Ind. Eng. Chem. Res. 2013, 52, 2304-2308

Kristia, Ignatius A. 2006. Karakteristik Anatomi Tiga Jenis Kayu Eucalyptus Dari Sumatera Utara. Fakultas Kehutanan, Institut Pertanian Bogor

Lutfi, Handoko.2018. Potensi Kenaf Indonesia Sebagai Bahan Baku Kertas. Bekasi: Fakultas Program Diploma. Institut Teknologi Dan Sains Bandung

Magaton, A. Da S., Colodette, J. L., Gouvêa, A. De F. G., Gomide, J. L., Muguet, M. C. D. S., \& Pedrazzi, C. (2009). Eucalyptus Wood Quality And Its Impact On Kraft Pulp Production And Use. Tappi Journal, 8(35), 32-39

Mindawati, N. Dan Pratiwi. 2008. Kajian Penetapan Daur Optimal Hutan Tanaman Acacia 


\section{Research Paper Vol 2, No 2, Tahun 2020}

Mangium Ditinjau Dari Kesuburan Tanah. Penelitian Hutan Tanaman Vo. 5 No.2. Juli 2008. Puslit Hutan Tanaman. Bogor.

Nambiar, E. K. S., \& Harwood, C. E. (2014b). Productivity Of Acacia And Eucalypt Plantations In South-East Asia. 2. Trends And Variations. International Forestry Review, 16(2), 225-248.

Pasaribu R. A. dan Tampubolon 1997. Persyaratan Teknis Bahan Baku, Air, dan Bahan Penolong untuk Industri, Kertas dan Rayon. Diktat Pelatihan Verivfikasi Eksportir Produk Industri Kehutanan. Puslitbang Teknologi Hasil Hutan, Bogor.

Pasaribu, R.A., Dan H. Roliadi. 1990. Pengolahan Pulp Secara Kimia. Bogor. Pusat Penelitian Dan Pengembangan Hasil Hutan Dan Sosek Kehutanan. 19 Hal.

Purba, R, 1999. Pengaruh Efektif Mikroorganisme EM4 terhadap Dekomposisi Serasah Eucalyptus. Fakultas Universitas Simalungun Pematang Siantar.

Roliadi, Han, Dulsalam dan Dian Anggraini. 2010. Penentuan Daur Teknis Optimal Dan Faktor Eksploitasi Kayu Hutan Tanaman Jenis Eucalyptus Hybrid Sebagai Bahan Baku Pulp Kertas. Pusat Litbang Keteknikan Dan Pengolahan Hasil Hutan.

Segura, T. T., Zanao, M., Santos, J. R., \& Silva Jr, F. (2012). Kraft Pulping Of The Main Hardwoods Used Around The World For Pulp And Paper Production. Tappi Peers. (Pp. 1592 1623).

Siagian, T. Y. 1994, Percobaan Provenansi Eucalyptus Urophylla S.T. Blake (The Eucalyptus Urophylla S.T. Blake Provenance Trial).

Sihite, Osloria. 2008. Siagian, T. Y. 1994, Percobaan Provenansi Eucalyptus Urophylla S.T. Blake
(The Eucalyptus Urophylla S.T. Blake Provenance Trial).Tesis. Medan : Universitas Sumatera Utara

Sindusuwarno, D.R, D.I., Utomo. 1981. Acacia Mangium Jenis Pohon Yang Belum Banyak Dikenal. Kehutanan Indonesia Vi (Ii) : 38-41.

Sixta, Herbet. 2006. Handbook Of Pulp. Weinheim:Wiley-Vch Verlag Gmbh \&Co. Kgaa

Sjostrom, E. 1995. Kimia Kayu, Dasar-Dasar Dan Penggunaan Edisi Kedua.

Smook, Garry A. 2002. Handbook For Pulp And Paper Technologists. Bellingham:Angus Publication Inc

Sugesty Susi, Teddy Kardiansyah,Dan Wieke Pratiwi.2015.Potensi Acacia Crassicarpa Sebagai Bahan Baku Pulp Kertas Untuk Hutan Tanaman Industry. Jurnal Selulosa, Vol. 5, No. 1, Juni $2015: 21$ - 3

Suhartati, Yanto Rahmayanto Dan Y. Daeng. 2014. Dampak Penurunan Daur Tanaman Hti Acacia Terhadap Kelestarian Produksi, Ekologis Dan Sosial. Info Teknis Eboni. Vol. 11 No. 2, Desember 2014 : 103 - 116

Sulistyo Rini, Annisa. 2019. Industri Pulp Dan Kertas Indonesia Masuk $10 \quad$ Besar Dunia.https://ekonomi.bisnis.com/read/201901 27/257/882862/industri-pulp-dan-kertasindonesia-masuk-10-besar-dunia (Diakses 20 Juni 2020)

Wardany, Hendry Pramudiyo. 2002. Analisis Sifat Kimia Dan Sifat Anatomi Kayu Amngium Dari Berbagai Provenasi. Bogor: Fakultas Kehutanan. Institut Pertanian Bogor Yogyakarta: Gadjah Mada University Press. 